\title{
A multilevel model with clustered management practices differentiating dairy herd environments in southeastern Sicily
}

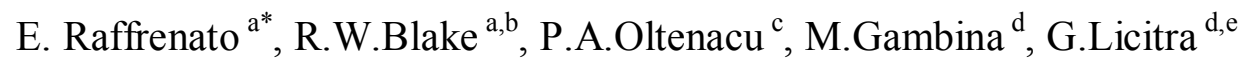 \\ a Department of Animal Science, Cornell University, Ithaca, NY 14853, USA \\ ${ }^{\mathrm{b}}$ Department of Animal Science and Center for Latin American and Caribbean Studies, Michigan State \\ University, USA \\ ${ }^{\mathrm{c}}$ Department of Animal Science, Oklahoma State University, Stillwater 74078, USA \\ ${ }^{\mathrm{d}}$ CoRFiLaC, Regione Siciliana, 97100 Ragusa, Italy \\ e Dipartimento di Scienze delle Produzioni Agrarie e Alimentari (DISPA), Università di Catania, 95100 \\ Catania, Italy \\ * Correspondence to: Department of Animal and Wildlife Sciences, University of Pretoria, Private Bag \\ x20, Hatfield 0023, Pretoria, South Africa. Tel.: +27 124206736.
}

\begin{abstract}
Herd environments constitute productivity potentials, or aggregate opportunity outcomes, resulting from management actions taken with the available inputs. Management outcomes from cow nutrition, udder health and milking practices were quantified with the help of surveys of 254 dairy producers in southeastern Sicily. Objectives were to disentangle environmental opportunities by disaggregating herd effects into causal inputs. Average ME milk production was $8640 \mathrm{~kg} /$ lactation for the 183 Friesian herds containing 35 lactating cows and 10 dry cows. Seventy-one Brown Swiss herds averaged $6443 \mathrm{~kg}$ ME milk from 25 lactating and 10 dry cows. For Friesian (Brown Swiss) herds 10 (11) management practices affected milking performance and $9(8)$ practices influenced somatic cell concentration $(P<0.05)$. Multilevel analysis and herd clustering procedures differentiated low from high opportunity herd environments but altering relative weightings among management practices did not further discriminate them. This clustering methodology helps ensure unbiased estimation of management input effects and could help target priority management substitutions and technical support priorities in dairy extension programs.
\end{abstract}

\section{Keywords}

- Herd environmental definitions;

- Management practices;

- Animal breeding 


\section{Introduction}

In dairy cattle breeding, genetic evaluations are calculated from performance data collected on each cow at the farm and pedigree information. Cow performance comprises genetic potential (i.e., its genotype) and the environmental opportunity corresponding to a given record. Many environmental factors affect cow performance (e.g., climatic conditions, diet and feeding methods, disease exposure) and may lead to unequal genetic expression from genotype by environment interactions (Raffrenato et al., 2003). Typically herd management factors are treated as fixed herd-year-season effects. This adjustment to the average herd environmental opportunity ignores the specific marginal contributions of management inputs on cow performance (e.g., milk production, udder health, reproduction).

In addition to country or geographic region to distinguish alternative environmental opportunities, herds in many studies have been classified especially by mean herd milk production (Danell, 1982, De Veer and Van Vleck, 1987 and Norman et al., 1988) and its variance using within herd-year-season or herd-year standard deviations (HYSD) (Carvalheira et al., 1998, Cienfuegos-Rivas et al., 1999, Castillo-Juarez et al., 2000, Costa et al., 2000 and Short et al., 1990). Few other criteria have been used to define herd environments. Banos and Shook (1990) used herd average somatic cell score as an udder health management indicator. CastilloJuarez et al. (2000) distinguished alternative herd environments by combining mature equivalent (ME) milk herd mean, HYSD and mean body weight divided by age at first calving. Windig et al. (2005) defined herd environment by grouping 41 variables into four principal components derived from cow productivity. Herd classifications based on performance variances assume that herds with larger (smaller) within herd milk yield standard deviations provide greater (diminished) cow performance opportunities. Usai et al. (2006) instead used principal component and cluster analyses to stratify 151 Sardinian goat flocks into three management systems based on inputs of nutrition, health and reproduction.

Sicilian dairy farmers utilize two production systems: low-input grazing and a high-input confinement. Traditional grazing systems typically utilize Brown Swiss or Modicana cows for the manufacture of Ragusano, provola, and ricotta cheeses. Farmers owning herds under confinement, generally higher-yielding Holstein-Friesian cows, produce milk for fluid and manufacturing purposes relying on harvested forages (Licitra et al., 1998). Farms in these systems differ in their resource endowments, input allocations, training of personnel, and management skills and preferences. Therefore, because herd stratification based on average cow performance, or within-herd variance, is only indirectly coupled to causal inputs, estimates of genetic and residual variances may be biased (Famula, 1989). Consequently, our objective was to evaluate a methodology where herd environmental opportunity is specified as a function of inputs administered through practices ascertained from herd manager interviews comparing it with the frequently-used HYSD criterion ignoring this causal information.

\section{Material and methods}

A survey of the 292 dairy farms enrolled in the local province dairy recording program, Associazione Provinciale Allevatori (APA), was conducted in collaboration with a local dairy research center, Consorzio Ricerca Filiera Lattiero-Casearia (CoRFiLaC). Owners were 
personally interviewed by questionnaire comprising sections on general herd description and management practices regarding health, nutrition, milking procedures, housing information, and reproduction. Most questions were close-ended with a list of predetermined alternatives to facilitate clarity of response, and so that responses could be entered directly for data processing.

Three interviewers were trained and provided with guidelines for potentially uncooperative respondents and unanticipated responses. Pre-testing was assessed by some farmers also belonging to the APA administration council who verified final format and clarity of the questions. Survey respondents were initially contacted by telephone to explain the purpose of the study and to request an appointment. More costly than a mail survey, personal interviews are more likely to generate accurate information. Responses were evaluated for reliability by local extension agents and by nutritionists from local feed companies. Eighty-seven percent of the total APA membership participated in the study, which included 183 Friesian and 71 Brown Swiss herds.

Herd productivity data, provided by the APA, consisted of ME milk production and somatic cell score records $\left(\mathrm{SCS}=\log _{2}\right.$ (somatic cell count $\left./ 100,000\right)+3$ ) from 4114 Friesian and 880 Brown Swiss cows in these herds. A weighted somatic cell score (WSCS) was obtained for each lactation record using test day milk yields $\left(m_{i}\right)$ as weighting factors to adjust for stage of lactation:

WSCS $=\frac{\sum_{i=1}^{n}\left(m_{i} \times \operatorname{SCS}_{i}\right)}{\sum_{i=1}^{n} m_{i}}$.

A total of 32 management practices (Table 1) on milking, health and nutrition management and housing conditions were examined for ostensible relationships with lactation performance and WSCS. Selection was for those practices believed or shown to influence milk yield or mammary health. For simplicity, independent variables were uniformly coded as binary variables (present or absent) even if continuous variables (as opposed to binary) would have permitted quantifying responses to the use intensity of a practice.

Table 1. Management categories, variables and their use frequencies (\%) for all herds.

\section{Management practices}

Nutrition management

Use of a nutrition consultant

Feeding silage

Forage analysis

TMR for lactating cows

Pasture in the diet

\section{Friesian Brown Swiss}

$\begin{array}{ll}93 & 86 \\ 74 & 54 \\ 54 & 15 \\ 44 & 15 \\ 37 & 50\end{array}$




\section{Management practices}

Mineral supplements for lactating cows

TMR for dry cows

TMR for heifers

Feeding groups

Haylage

\section{Friesian Brown Swiss}

$28 \quad 29$

$16 \quad 12$

$16 \quad 11$

149

$14 \quad 10$

\section{Milking management}

Equipment washed with detergent at least 2/day $84 \quad 83$

$\begin{array}{lll}\text { Postpone milking if milk is abnormal } & 78 & 87\end{array}$

$\begin{array}{lll}\text { Fore stripping before milking } & 57 & 57\end{array}$

$\begin{array}{lll}\text { Teats dried after pre-dip or washing } & 57 & 52\end{array}$

$\begin{array}{lll}\text { Cows milked in milking parlor } & 53 & 77\end{array}$

Post milking teat disinfection $\quad 49 \quad 38$

Equipment professionally checked at least 2/year $47 \quad 42$

Use of dry towels before milking $\quad 38 \quad 25$

1-day dry off $\quad 33 \quad 23$

Analysis of abnormal milk $\quad 29 \quad 30$

$\begin{array}{lll}\text { Postpone milking if abnormal milk } & 24 & 37\end{array}$

Health management

$\begin{array}{lll}\text { Use of antibiotics to treat clinical mastitis } & 78 & 77\end{array}$

Antibiotic dry cow treatment $\quad 66 \quad 66$

Milk discarded with presence of antibiotics $\quad 30 \quad 40$

Record-keeping system

$17 \quad 6$

Housing

Shade during the summer $\quad 89 \quad 84$

$\begin{array}{lll}\text { Bedding } & 78 & 68\end{array}$

Newborn calves housed in individual pens $\quad 63 \quad 47$

Special pen for sick cows $\quad 54 \quad 40$

$\begin{array}{lll}\text { Maternity pen } & 34 & 15\end{array}$

Others

Consulting for general information

$78 \quad 72$

Semen storage tank

$46 \quad 26$

A two-level unconditional means model was applied to these hierarchically structured data to estimate the effects of management practices on lactation performance and WSCS. Dairy farming provides a clear case of a system in which individuals (cows) are subject to the influence of grouping (herds). Such a model partitions variation at each specified level, which accounts for 
important dependencies from herd clusters (Raudenbush, 2002). The collected data may be imbalanced at any level. In our case cow-level outcomes $Y_{i j}$ were depicted with two linked models: one for the cow and another for its herd (Proc MIXED, SAS version 9.1, SAS Institute Inc., Cary, NC). Cow-level outcomes were represented as the sum of the intercept for the herd effect plus a random error term associated with each animal. For herd outcomes, the intercept was expressed as the sum of the grand mean plus sequences of random deviations according to invoked management practices. Season of calving was added to the basic model as a cow level predictor: season 1 corresponded to calvings from November through February; season 2 for calvings from March through May; and season 3 for the remainder of the year. By adding this level-one predictor not only are outcomes obtained as a function of the cows' season of calving but the specified relationship between the outcome and calving season may vary across herds. Consequently, the model contains intercepts and slopes that vary across herds. After addition of the first explanatory variable $x_{1}$ (Rasbash, 2000) the basic multilevel model becomes

(2) $Y_{i j}=b_{0}+b_{1} x_{1 i j}+u_{j}+e_{i j}$

where $Y_{i j}$ is the mature equivalent milk record or WSCS for the $i$ th cow in the $j$ th herd, $b_{0}$ is the overall intercept across herds, $b_{1}$ is the regression coefficient for the explanatory variable season of calving $x_{1 i j}$ for the $i$ th cow in the $j$ th herd, $u_{j}$, the level 2 residual, is the departure of the $j$ th herd's intercept from the overall value, which is the same for all cows in herd $j$. Both $u_{j}$ and $e_{i j}$ are random quantities, whose means are equal to zero. We assume these variables to be uncorrelated and distributed normally with variances $\hat{\sigma}^{2}{ }_{u}$ and $\hat{\sigma}_{e}^{2}$, respectively. Collecting the coefficients to specify the random variation in $Y$ in terms of random coefficients of the explanatory variable, then

(3)

$Y_{i \bar{y}}=b_{0 \bar{y}}+b_{1} x_{1 \bar{j}}$ and

(4)

$b_{0 i j}=b_{0}+u_{0 j}+e_{0 i j}$.

The goal of this multilevel analysis is to estimate the pattern of variation in the underlying population of herds, not individual herds in our sample. This pattern may be explained in terms of general farm characteristics and by other management variables (practices) included in the model.

Forward stepwise variable selection aided the selection of herd level practices (Table 1) to include in the final model, thus making it conditional upon the fixed effects from these practices. The initial probability value was set to 0.05 and the remaining one at 0.10 for both breeds. Multicollinearity was ignored because every variance inflation factor was less than 10 (Neter et al., 1996). The selected management variables were used to cluster herds into low and high opportunity environments. The final model thus extended with further explanatory variables at the herd-level becomes 
(5)

$Y_{i j}=b_{0}+b_{1} \times_{1 i j}+\left(u_{0 j}+u_{1 j} x_{i j}+\sum_{h=2}^{p} b_{h} x_{h i j}+e_{0 i j}\right)$

where $h$ represents management factors from 2 to $p$. To account for heteroscedasticity, the error term was modified according to Pinheiro and Bates (2000) to permit unequal variances at each herd level. Likelihood ratio tests (Pinheiro and Bates, 2000) with a high $P$-value (0.34) of the likelihood ratio statistic and the plots of standardized residuals versus fitted values by herd confirmed that the heteroscedastic model did not better explain the data than the homoscedastic model. The assumption of normality for the within-group errors was confirmed using normal probability plots of the residuals. The lowest level of aggregation (cow) was not tested because sample size did not allow convergence of the heteroscedastic model at such a low level. Common variance functions used in mixed-effects analysis were also tested (Pinheiro and Bates, 2000).

\subsection{Herd environment clustering}

\subsubsection{Management practices}

Questionnaire responses provided herd clustering criteria and contrasting low and high opportunity environments. Distance of Jaccard dissimilarity coefficients were created for each herd using the Distance Macro in SAS (Kuo, 1997). An asymmetric binary variable indicating presence or absence of a management practice was associated with each response. Asymmetry arises because potential outcomes may be unequal. The most important outcome was the presence of a specific practice. Agreement between two invoked practices (positive match) outweighs absent agreement (negative match). Distance of Jaccard matrices were created with and without weights for practices associated with milk yield, for practices associated with WSCS, and for their combination. The management distance of Jaccard between two farms, $x x$ and $y$, was calculated:

$d(x, y)=\frac{\sum_{i=1}^{n} \delta_{x, y}^{i}}{\sum_{i=1}^{n} \xi_{x, y}^{i}+\sum_{i=1}^{n} \delta_{x, y}^{i}}$,

where $n$ is the total number of criteria considered, $\delta_{x, y}=1$ if $x_{i} \neq y_{i}$, otherwise $\delta_{x, y}=0$ and $\vartheta_{x, y}=1$ if $x_{i}=y_{i}$, otherwise $\vartheta_{x, y}=0$.

Clustering is a hierarchical agglomerative method for constructing kinship groups from multivariate data. In our case groups represent similar environmental conditions determined by herd management. The Lance-Williams (Lance and Williams, 1967) flexible-beta method was used, where the value of beta is the weight assigned to the new within-cluster distance after merging two clusters into a single partition. As recommended by Milligan (1989) when outliers 
are anticipated, a beta value of -0.5 was used to guard against influential (less accurately informed) outliers. A beta value of -0.5 instead of -0.25 has been shown to provide greater information recovery when clustering is more diverse (Scheibler and Schneider, 1985). Assuming merged clusters $K$ and $L$ form cluster $M$, the distance $(D)$ between $J$ and $M$ was specified as

$D_{J M}=\left(D_{J K}+D_{J L}\right)(1-\beta) / 2+D_{K L} \beta$

Herds in low and high opportunity environments were clustered giving equal weight to practices, and by assigning more weight to practices significantly associated with herd milk production, herd WSCS, or to both outcomes, based on results from the multilevel model. Performance levels and management practices were therefore analyzed in the herd clusters obtained.

\subsubsection{Within-herd-year standard deviation}

The phenotypic within herd-year standard deviation (HYSD) for 305-day ME milk yield, a common proxy for environmental opportunity, was also used to discriminate herds, separating them into high and low opportunity groups (like in studies of genotype $\times$ environment interaction), especially where diets are limiting (Boldman and Freeman, 1990, Cienfuegos-Rivas et al., 1999, Costa et al., 2000, Dong and Mao, 1990, Raffrenato et al., 2003 and Stanton et al., 1991). Low opportunity Friesian (Brown Swiss) herds were defined as those with HYSD $<1260 \mathrm{~kg}$ (HYSD<990 kg). High opportunity Friesian (Brown Swiss) herds were those with $H Y S D \geq 1260 \mathrm{~kg}$ (HYSD $\geq 990 \mathrm{~kg})$.

\section{Results}

Records showed that calvings throughout the year were distributed with a slightly greater occurrence during the fall months. However, average ME milk yield by month of calving showed that cows calving during spring months had highest yields $(9200 \mathrm{~kg}$ for Friesian, $7100 \mathrm{~kg}$ for Brown Swiss). Friesian herds averaged $8640 \mathrm{~kg}$ ME milk. Brown Swiss herds averaged $6443 \mathrm{~kg}$ ME milk. Largest SCS values were during the rainy months of December and January (4.05 for Friesian and 4.35 for Brown Swiss).

Survey responses revealed important variability in the inputs applied by managers of these production systems, as anticipated. While our objective focuses on the multilevel and clustering methodology, survey results may be obtained from Raffrenato (2002).

\subsection{Association between management practices and milk yield and WSCS}

The basic multilevel model (without predictors) for milk yield was highly explanatory $(P<0.0001)$ in each production system. The estimated $\hat{\sigma}^{2}{ }_{u} \mathrm{~s}$ are $2,609,686 \mathrm{~kg}^{2}$ and $1,410,428 \mathrm{~kg}^{2}$ and $\hat{\sigma}_{e}^{2}$ s are 2,157,750 $\mathrm{kg}^{2}$ and $1,070,575 \mathrm{~kg}^{2}$ for Friesian and Brown Swiss, respectively. Herds differed in milk yield and with smaller variances among cows within herds than across herds, as 
expected. The estimated herd effects of $8898 \mathrm{~kg}$ and $6378 \mathrm{~kg}$ accurately reflected the average herd-level milk yield for Friesian and Brown Swiss herds.

The results from the model conditional on the predictors are given in Table 2 and Table 3 . The meaning of the intercept variances (variance between herds) differs from those in the unconditional model because they depend on the presence of management practices. As expected, the residual components (variances within herds) were nearly unchanged, however the variances between herds decreased substantially for both production systems. The estimated $\hat{\sigma}^{2}{ }_{u} \mathrm{~s}$ are $987,219 \mathrm{~kg}^{2}$ and $341,536 \mathrm{~kg}^{2}$ and $\hat{\sigma}_{e}^{2} \mathrm{~s}$ are $2,145,763 \mathrm{~kg}^{2}$ and $1,049,784 \mathrm{~kg}^{2}$ for Friesian and Brown Swiss herds, respectively.

Table 2. Results from the conditional means model with predictors included for ME milk (kg) for Friesian.

Covariance parameter

Intercept (herd)

Residual

Fixed effect solution

Intercept

Season $1^{\text {a }}$

Season $2^{\text {a }}$

Nutrition management

TMR for lactating cows

Haylage

Forage analysis

Pasture in the diet
Estimate Standard error $\boldsymbol{P}$-value

$987,219 \quad 401,867$

$<0.0001$

2,145,763 45,929

$<0.0001$

$11,885 \quad 402$

$<0.001$

250

52

$<0.001$

178

57

0.002

$918 \quad 213$

$<0.001$

$701 \quad 240$

0.004

395

192

0.041

$-159 \quad 92$

0.091

Milking management

Equipment professionally checked at least 2/year 490

182

0.008

Post milking teat disinfection

366

179

0.002

Health management

Antibiotic dry cow treatment

$502 \quad 202$

0.061

Record-keeping system

381

231

$<0.001$

Use of antibiotics to treat clinical mastitis

379

214

0.079

Others

Semen storage tank

747

196

$<0.001$

\footnotetext{
${ }^{a}$ Season 1 includes November through February; season 2 includes March through May.
} 
Table 3. Results from the conditional means model with predictors included for ME milk for Brown Swiss.

\begin{tabular}{|c|c|c|c|}
\hline Covariance parameter & Estimate & Standard error & $P$-value \\
\hline Intercept (herd) & 341,536 & 113,933 & 0.0014 \\
\hline Residual & $1,049,784$ & 61,302 & $<0.0001$ \\
\hline \multicolumn{4}{|l|}{ Fixed effect solution } \\
\hline Intercept & 7868 & 679 & $<0.001$ \\
\hline Season $1^{\text {a }}$ & 365 & 107 & 0.001 \\
\hline Season $2^{a}$ & 362 & 100 & $<0.001$ \\
\hline \multicolumn{4}{|l|}{ Nutrition management } \\
\hline TMR for lactating cows & 1367 & 454 & 0.004 \\
\hline Use of a nutrition consultant & 714 & 313 & 0.028 \\
\hline Silage & 528 & 202 & 0.013 \\
\hline Pasture in the diet & -1250 & 375 & $<0.002$ \\
\hline \multicolumn{4}{|l|}{ Milking management } \\
\hline Cows milked in milking parlor & 1198 & 251 & $<0.001$ \\
\hline Equipment washed with detergent at least 2 /day & 748 & 287 & 0.012 \\
\hline Post milking teat disinfection & 679 & 265 & 0.014 \\
\hline Postpone milking if milk is abnormal & 640 & 251 & 0.015 \\
\hline Teats dried after pre-dip or washing & 365 & 215 & 0.010 \\
\hline \multicolumn{4}{|l|}{ Health management } \\
\hline Record-keeping system & 2007 & 504 & $<0.001$ \\
\hline Antibiotic dry cow treatment & 707 & 229 & 0.003 \\
\hline \multicolumn{4}{|l|}{ Others } \\
\hline Semen storage tank & 850 & 250 & 0.001 \\
\hline
\end{tabular}

Smaller values of $\hat{\sigma}^{2}{ }_{u}$ indicate that approximately $63 \%$ and $76 \%$ of the variance in mean milk production among Friesian and Brown Swiss herds were accounted by the management practices in the final model. Howard et al. (1987) found that $26 \%$ of the variance in milk yield was accounted by a cubic function of SCC and six productivity variables (SCS was regressed on 17 management practices). The large decrease in herd variance obtained in this study indicates that our hierarchical linear model effectively disentangled underlying management factors within herds (Osborne, 2000).

The basic multilevel model $(P<0.001)$ for WSCS resulted in estimated $\hat{\sigma}^{2}{ }_{u}$ s of 0.671 and 0.817 and $\hat{\sigma}_{e}^{2}$ s of 2.206 and 1.914 for Friesian and Brown Swiss herds, respectively. As for milking performance, herds differed $(P<0.001)$ in WSCS and had smaller variances among cows within 
herds, than across them. The estimated herd effects of 3.822 and 4.052 represent the average herd-level WSCS for Friesian and Brown Swiss, respectively.

Results conditional on the predictors for WSCS are in Table 4 and Table 5. Management predictors of WSCS explained about $62 \%$ of the variance among Friesian herds and $78 \%$ for Brown Swiss herds. More practices were included in the model for Brown Swiss herds than for Friesian (8 vs. 6). Van Schaik et al. (2005) used backward elimination in multiple linear regression models to remove inconsequential $(P>0.05)$ management factors to explain $35 \%$ of the variance in total bacterial count and $18 \%$ of the variance of somatic cell count. For Friesian (Brown Swiss) herds, all management practices but one were favorably associated $(P<0.10)$ with milking performance ( Table 2 and Table 3), as were all practices related to WSCS ( Table 4 and Table 5). Grazing (pasture use) was the management exception not favoring productivity $(P=0.097)$. This outcome likely signifies poor control of dietary (low forage) quality, slightly depressing ME milk in high-input Holstein herds, and with large opportunity losses in milk in Brown Swiss herds. In these herds, relying on grazing effectively cancels (precludes) the potential large increment in milk expected from the greater nutrient intake from TMR $(P<0.001)$.

Table 4. Results from the conditional means model with predictors included for WSCS for Friesian.

\begin{tabular}{llll}
\multicolumn{1}{c}{ Covariance parameter } & \multicolumn{3}{c}{ Estimate Standard error $\boldsymbol{P}$-value } \\
Intercept (herd) & 0.391 & 0.062 & $<0.001$ \\
Residual & 2.190 & 0.049 & $<0.001$ \\
Fixed effect solution & & & \\
Intercept & 2.835 & 0.185 & $<0.001$ \\
Season 1 $^{\text {a }}$ & 0.191 & 0.577 & 0.001 \\
Season 2 $^{\text {a }}$ & 0.349 & 0.577 & $<0.001$ \\
Nutrition management & & & \\
Forage analysis & -0.411 & 0.120 & 0.006 \\
Mineral supplements for lactating cows & -0.405 & 0.128 & 0.020 \\
Pasture in the diet & 0.101 & 0.042 & 0.097 \\
Milking management & & & \\
Cows milked in milking parlor & -0.590 & 0.129 & $<0.001$ \\
Health management & & & \\
Antibiotic dry cow treatment & -0.363 & 0.128 & 0.054 \\
Housing & & & \\
Newborn calves housed in individual pens -0.264 & 0.121 & 0.031 \\
${ }^{a}$ Season 1 includes November through February; season 2 includes March through May.
\end{tabular}


Table 5. Results from the conditional means model with predictors included for WSCS for Brown Swiss.

\begin{tabular}{|c|c|c|c|}
\hline Covariance parameter & Estima & Stand & $P$-value \\
\hline Intercept (herd) & 0.180 & 0.087 & 0.019 \\
\hline Residual & 1.919 & 0.114 & $<0.001$ \\
\hline Fixed effect solution & & & \\
\hline Intercept & 4.337 & 0.407 & $<0.001$ \\
\hline Season $1^{\text {a }}$ & 0.293 & 0.147 & 0.049 \\
\hline Season $2^{a}$ & 0.277 & 0.133 & $<0.040$ \\
\hline Nutrition management & & & \\
\hline Mineral supplements for lactating cows & 0.445 & 0.206 & 0.036 \\
\hline Milking management & & & \\
\hline Teats dried after pre-dip or washing & 0.983 & 0.210 & $<0.001$ \\
\hline Post milking teat disinfection & 0.589 & 0.213 & 0.008 \\
\hline Postpone milking if milk is abnormal & 0.487 & 0.211 & 0.025 \\
\hline Health management & & & \\
\hline Antibiotic dry cow treatment & 0.485 & 0.210 & 0.025 \\
\hline Housing & & & \\
\hline Shade during the summer & 0.794 & 0.235 & 0.001 \\
\hline Maternity pen & 0.559 & 0.263 & 0.039 \\
\hline Others & & & \\
\hline Semen storage tank & 0.909 & 0.215 & 0.001 \\
\hline
\end{tabular}

Results showed milk production was increased principally by more effective feeding practices: the use of TMR, haylage (silage), and chemical evaluation of forage quality. Antibiotic dry cow treatment was likely the most important health practice by its mutual favorable associations with WSCS and milk production across all herds. Other variables associated with increased milk yield were post-milking teat disinfection and information-based management. Herds milking cows in a parlor instead of a barn obtained lowest SCS.

\subsection{Herd environments for milk yield and WSCS}

Table 6 and Table 7 show the numbers of herds and average cow performance in the contrasting environments defined by all management practices, weightings of selected practices, and by the HYSD criterion. High opportunity herds had greater mean milk production with lower somatic cell scores than the low opportunity ones. When selected management practices (Table 2, Table 3 , Table 4 and Table 5) were weighted, the performance difference between high and low 
environmental clusters increased in both production systems. However, differences in HYSD were unaffected by these alternative definitions, which indicate low sensitivity to the causal pathways determining milk yield or mammary health. Smaller herds in general provided less privileged environments, as described by Licitra et al. (1998).

Table 6. High and low opportunity environments by clustering criterion and relative average size, and production $(\mathrm{kg})$ of milk, protein and fat, and somatic cell score by Friesian cows.

\begin{tabular}{|c|c|c|c|c|c|}
\hline \multirow{2}{*}{$\begin{array}{l}\text { Clustering criteria and relative management } \\
\text { level/environment } \\
\text { Unweighted }^{\text {a }}\end{array}$} & \multicolumn{2}{|c|}{ Herds Size } & \multirow[t]{2}{*}{ Milk } & \multicolumn{2}{|c|}{ Fat Protein Score } \\
\hline & & & & & \\
\hline High & 91 & 56 & 10,191 & 327315 & 3.40 \\
\hline Low & 92 & 33 & 8184 & 276249 & 4.12 \\
\hline \multicolumn{6}{|l|}{ Weighted for milk ${ }^{\mathrm{b}}$} \\
\hline High & 74 & 60 & 10,368 & 3330320 & 3.36 \\
\hline Low & 109 & 34 & 8250 & 275252 & 4.06 \\
\hline \multicolumn{6}{|l|}{ Weighted for WSCS ${ }^{\mathrm{c}}$} \\
\hline High & 114 & 52 & 9933 & 321306 & 3.50 \\
\hline Low & 69 & 32 & 8045 & 270244 & 4.15 \\
\hline \multicolumn{6}{|l|}{ Combined $^{\mathrm{d}}$} \\
\hline High & 87 & 55 & 10,149 & 326313 & 3.51 \\
\hline Low & 96 & 35 & 8321 & 279255 & 3.96 \\
\hline \multicolumn{6}{|l|}{$H Y S D^{\mathrm{e}}$} \\
\hline High & 92 & 52 & 10,173 & 329314 & 3.46 \\
\hline Low & 91 & 36 & 8458 & 278258 & 3.93 \\
\hline
\end{tabular}

${ }^{a}$ Unweighted clustering based on all management practices.

${ }^{\mathrm{b}}$ Weights applied to 10 selected management practices from regression on milk.

${ }^{\mathrm{c}}$ Weights applied to 6 selected management practices from regression on WSCS.

${ }^{\mathrm{d}}$ Weights applied to 16 selected practices from regressions on milk and WSCS.

${ }^{\mathrm{e}}$ HYSD classes: low, $<1260 \mathrm{~kg}$; high, $>1260 \mathrm{~kg}$ of milk.

Feeding management practices in the multilevel model resulted in different use frequencies between high and low opportunity groupings, while other practices did not. This probably means that the mere existence of a practice in a management protocol (Table 2 and Table 3 ), as opposed to the intensity of its use, did not further differentiate management potentials within a specific herd opportunity classification. Milking practices effectively discriminated between opportunity classes for WSCS in both production systems. However alternative weightings did not better distinguish low from high-level opportunity herds. Most herds remained in the same class. Under these circumstances weighting might indirectly introduce bias. In contrast, the herd groups based on the HYSD criterion did not differentiate herds for milk production or WSCS $(P>0.05)$. 
Table 7. High and low opportunity environments by clustering criterion and relative average size, and production $(\mathrm{kg})$ of milk, protein and fat, and somatic cell score by Brown Swiss cows.

\section{Clustering criteria and relative management level/environment}

\section{Herds Size Milk Fat Prot Score}

Unweighted $^{\mathrm{a}}$

High

$\begin{array}{llllll}32 & 49 & 7842 & 282 & 253 & 3.63\end{array}$

Low

$39 \quad 34 \quad 6050220212 \quad 4.04$

Weighted for milk

High

$\begin{array}{llllll}33 & 50 & 8120 & 286 & 251 & 3.77\end{array}$

Low

$38 \quad 32 \quad 5772216206 \quad 3.88$

Weighted for WSCS $^{\mathrm{c}}$

High

$34 \quad 48 \quad 78122792643.66$

Low

$\begin{array}{llllll}37 & 34 & 6081223201 & 3.99\end{array}$

Combined $^{\mathrm{d}}$

High

$35 \quad 46 \quad 8010285250 \quad 3.60$

Low

$36 \quad 36 \quad 5883217205 \quad 4.05$

HYSD $^{\mathrm{e}}$

High

Low

$36 \quad 39 \quad 6248226210 \quad 3.98$

${ }^{\text {a }}$ Unweighted clustering based on all management practices.

${ }^{\mathrm{b}}$ Weights applied to 12 selected management practices from regression on milk.

${ }^{\mathrm{c}}$ Weights applied to 8 selected management practices from regression on WSCS.

${ }^{\mathrm{d}}$ Weights applied to 20 selected practices from regressions on milk and WSCS.

${ }^{\mathrm{e}}$ HYSD classes: low, <930 kg; high, $>930 \mathrm{~kg}$ of milk.

The multilevel methodology used in this study clearly discriminated low and high herd environmental opportunities based on key management inputs obtained by surveying herd managers of two dairy production systems. Thus, selected management practices can be effectively utilized to causally define herd environments, as also demonstrated in a genetic inquiry by Raffrenato et al. (2003). These management practices are specific for time and place, which means that they need to be scrutinized and updated in a given environment.

The integrated approach presented in this study incorporates as binary variables information about management practices for herds clustered into contrasting environments, which helps ensure unbiased estimation of management input effects. In the absence of management information, HYSD is an undesirable proxy for defining alternative environments because productivity outcomes (herd mean and variance) are themselves used to characterize performance opportunities instead of causal inputs in the management milieu. 


\section{Conclusions}

This study presented a methodology to differentiate herd environments in a structurally unbiased manner. Selected management practices, or inputs, particularly herd nutrition and health obtained by surveying the APA dairy population were utilized to define low and high herd environmental opportunities for milk production and udder health (WSCS). The principal management practices and information affecting milk yield and WSCS were the use of TMR, forage composition information, use of a nutrition consultant, the use of grazing in the diet, cows milked in a parlor, adequate washing of the milking equipment, the antibiotic dry cow treatment, routine professional checking of the milking parlor, and a post milking teat disinfection. All practices except grazing favorably affected cow (herd) performance.

The multilevel methodology in this study used information about management practices as binary variables to cluster herds into input-differentiated environments that are unbiased. For our Sicilian herd population this methodology resulted in different herd opportunity environments compared to the HYSD criterion. This outcome clearly reflected mean performances that varied with inputs bound to specifiable management practices without necessarily influencing withinherd variation. Therefore, a methodology predicated on causality is a preferable tool for evaluating management substitutions to improve herd productivity and associated benefits.

\section{Conflict of interest statement}

We wish to confirm that there are no known conflicts of interest associated with this publication and there has been no significant financial support for this work that could have influenced its outcome.

We confirm that the manuscript has been read and approved by all named authors and that there are no other persons who satisfied the criteria for authorship but are not listed. We further confirm that the order of authors listed in the manuscript has been approved by all of us.

We confirm that we have given due consideration to the protection of intellectual property associated with this work and that there are no impediments to publication, including the timing of publication, with respect to intellectual property. In so doing we confirm that we have followed the regulations of our institutions concerning intellectual property.

\section{Acknowledgments}

This project was partially funded by the CoRFiLaC (Ragusa, Italy) and Cornell University. The data were kindly provided by Associazione Nazionale Frisona Italiana, Associazione Nazionale Allevatori Razza Bruna and the CoRFiLac. We especially thank G. Tumino, M. Benvisto and G. Azzaro (technical staff of the CoRFiLac) for assistance in conducting the survey. The help of the Associazione Provinciale Allevatori is also gratefully acknowledged. All farmers that cooperated by answering our questions are gratefully acknowledged. 


\section{References}

Banos, G.E. Shook, G.E., 1990.Genotype by environment interaction and genetic correlations among parities for somatic cell count and milk yield. J. Dairy Sci., 73, pp. 2563-2573.

Boldman, K.G., Freeman, A.E., 1990. Adjustment for heterogeneity of variances by herd production level in dairy cow and sire evaluation1. J. Dairy Sci., 73, pp. 503-512.

Carvalheira, J.G.V., Blake, R.W., Pollak, E.J., Quaas, R.L., Duran-Castro, C.V., 1998. Application of an autoregressive process to estimate genetic parameters and breeding values for dairy milk yield in a tropical herd of Lucerna cattle and in US Holstein herds. J. Dairy Sci., 81, pp. $2738-2751$.

Castillo-Juarez, H., Oltenacu, P.A., Blake, R.W., Mcculloch, C.E., Cienfuegos-Rivas, E.G., 2000. Effect of herd environment on the genetic and phenotypic relationships among milk yield, conception rate, and somatic cell score in Holstein cattle. J. Dairy Sci., 83 (2000), pp. 807-814.

Cienfuegos-Rivas, E.G., Oltenacu, P.A., Blake, R.W., Schwager, S.J., Castillo-Juarez, H., Ruiz, F.J. 1999. Interaction between milk yield of Holstein cows in Mexico and the United States. J. Dairy Sci., 82, pp. 2218-2223.

Costa, C.N., Blake, R.W., Pollak, E.J., Oltenacu, P.A., Quaas, R.L., Searle, S.R., 2000. Genetic analysis of Holstein cattle populations in Brazil and the United States. J. Dairy Sci., 83, pp. 2963-2974.

Danell, B., 1982, Interaction between genotype and environment in sire evaluation for milk production. Acta Agric. Scand., 32, pp. 33-46.

De Veer, J., Van Vleck, L.D., 1987. Genetic parameters for first lactation milk yields at three levels of herd production. J. Dairy Sci., 70, pp. 1434-1441.

Dong, M.C., Mao, I.L., 1990. Heterogeneity of (co)variance and heritabitity in different levels of intraherd milk production variance and of herd average. J. Dairy. Sci., 73, pp. 843-851.

Famula, T.R., 1989. Detection of heterogeneous variance in herd production groups. J. Dairy Sci., 72, pp. 715-721.

Howard, W.H., Knight, T.O., Shumway, C.R., Blake, R.W., Tomaszewski, M.A., 1987. Information and herd health management practices in Texas dairies. South J. Agric. Econ., 19, pp. $1-10$.

Kuo, M., 1997. The DISTANCE Macro: Preliminary Documentation (second ed.) SAS Institute, Cary, NC Multivariate \& Numerical R\&D application division.

Lance, G.N., Williams, W.T., 1967. A general theory of classificatory sorting strategies. Comput. J., 9, pp. 373-380. 
Licitra, G., Blake, R.W., Oltenacu, P.A., Barresi, S., Scuderi, S., Van Soest, P.J., 1998. Assessment of the dairy production needs of cattle owners in southeastern Sicily. J. Dairy Sci., 81, pp. 2510-2517.

Milligan, G.W., 1989. A study of the beta-flexible clustering method. Multivar. Behav. Res., 24, pp. $163-176$.

Neter, J., Kutner, M.H., Nachtsheim, C.J., Wasserman, W., 1996. Applied Linear Statistical Models. (fourth ed.) Richard D. Irwin, Inc., Chicago, IL.

Norman, H., Powell, R., Wright, J., Cassell, B. 1988. Phenotypic and genetic relationship between linear functional type traits and milk yield for five breeds. J. Dairy Sci., 71, pp. 18801896.

Pinheiro, J.C., Bates, D.M., 2000. Mixed-effects models in S and S-PLUS. New York: Springer.

Osborne, J.W., 2000. Advantages of hierarchical linear modeling. Pract. Assess. Res. Eval., 7, pp. 2-7.

Raffrenato, E., 2002. Heterogeneous Genetic Variation in Yields of Milk and Milk Components in Alternative Herd Environments of Holstein-Friesian and Brown Swiss Cows in Southeastern Sicily. M.S. Thesis. Department of Animal Science, Cornell University, Ithaca, NY. 156 pp.

Raffrenato, E., Blake, R.W., Oltenacu, P.A., Carvalheira, J., Licitra, G. 2003. Genotype by environment interaction for yield and somatic cell score with alternative environmental definitions. J. Dairy Sci., 86, pp. 2470-2479.

Rasbash, J., 2000. A User's Guide to MLwiN. University of London, Institute of Education, Centre for Multilevel Modelling.

Raudenbush, S.W., 2002. Hierarchical Linear Models: Applications and Data Analysis Methods. (second ed.) Sage Publications, Thousand Oaks, California.

Scheibler, D., Schneider, W. 1985. Monte Carlo tests of the accuracy of cluster analysis algorithms: a comparison of hierarchical and nonhierarchical methods. Multivar. Behav. Res., 20, pp. 283-304.

Short, T.H., Blake, R.W., Quaas, R.L., Van Vleck, L.D., 1990. Heterogeneous within-herd variance. 1. Genetic parameters for first and second lactation milk yields of grade Holstein cows. J. Dairy Sci., 73, pp. 3312-3330.

Stanton, T.L., Blake, R.W., Quaas, R.L., Van Vleck, L.D., Carabaño, M.J., 1991. Genotype by environment interaction for Holstein milk yield in Colombia, Mexico, and Puerto Rico. J. Dairy Sci., 74, pp. 1700-1714. 
Usai, M.G., Casu, S., Molle, G., Decandia, M., Ligios, S., Carta, A., 2006. Using cluster analysis to characterize the goat farming system in Sardinia. Livest. Sci., 104, pp. 63-76.

Van Schaik, G., Green, L.E., Guzman, D., Esparza, H., Tadich, N., 2005. Risk factors for bulk milk somatic cell counts and total bacterial counts in smallholder dairy farms in the 10th region of Chile. Prev. Vet. Med., 67, pp. 1-17.

Windig, J., Calus, M., Veerkamp, R., 2005. Influence of herd environment on health and fertility and their relationship with milk production. J. Dairy Sci., 88, pp. 335-347. 